\title{
Chapter 11 \\ Commentary: An Economic View \\ on the Prospects of a Flood Defense \\ Related Development Rights Market \\ in Flanders
}

\author{
András Kis and Gábor Ungvári
}

Economic instruments have been increasingly favoured by decision makers in the field of environmental and water policy, as they can provide efficient, low-cost solutions compared to command and control or traditional legal instruments. Such instruments, however, are not without problems. Even relatively simple solutions, for instance, environmental taxes, can backfire if their design, monitoring or enforcement is problematic, while more sophisticated instruments, such as market-based solutions, need even more thoughtful design and implementation to become successful. Some instruments look attractive on paper but are cumbersome or not operational in reality. The Flemish attempt at tradable development rights provides a suitable illustration of the practical difficulties of introducing an economic instrument that seeks to solve a problem through the creation and operation of a new environmental market.

\section{The Origins of Demand and Supply}

In Flanders, an economic solution to changing zoning designations was sought because government-initiated, forced rezoning had proven to be tedious and slow and require large financial compensations. In the proposed market, the development right can be decoupled from the land that is destined to be rezoned, and this right can be purchased by other landowners who are located in areas where development is not restricted. The traded commodity is the development right itself. The problem with this solution from an economic perspective is the gap between supply and demand in the case of Flanders. Supply can be offered by landowners who are located in flood-prone areas with restricted development options, whose development rights

\footnotetext{
A. Kis $(\varangle) \cdot$ G. Ungvári

Regional Centre for Energy Policy Research, Budapest, Hungary

e-mail: andras.kis@rekk.hu

G. Ungvári

e-mail: gabor.ungvari@rekk.hu

(C) The Author(s) 2019

T. Hartmann et al. (eds.), Nature-Based Flood Risk Management on Private Land, https://doi.org/10.1007/978-3-030-23842-1_11
} 
were granted many years ago. In these areas, land with development rights is much more expensive than land without such rights, and this difference is the perceived value of the right itself that landowners would like to fetch in case they sell it.

Demand is generated by landowners outside of flood-prone areas who would like to develop their land. These actors, however, usually have other, cheaper alternatives than buying development rights from areas that are to be rezoned. As Crabbé and Coppens suggest, many developers can acquire such rights from their respective local authorities without much hassle and at a relatively low price. Therefore, there is little demand for development rights, and even that demand is priced low. No wonder that supply and demand cannot really meet.

\section{How Could the Government Stimulate the Market?}

In such a situation, an economist may wonder if demand and supply can be bridged through government intervention. A specific sort of intervention could be of administrative nature - restricting the issue of new development rights throughout Flanders for a set period of time, in order to provide incentives for the market-based transfer of these rights from flood-prone areas to other locations. The feasibility of this option is not clear to us, but we imagine it may create much dissatisfaction among developers.

Another alternative is that of a subsidy. Since the traditional approach is for the government to pay landowners to give up their rights, the government may as well pay market participants to facilitate transactions in the development rights market, thus reducing the price for the buyer or increasing the revenue for the seller. As the payment by the government can be lower than the usual practice of compensation based on land prices, the government can also benefit from this solution.

A related critical question, however, is not addressed in the paper: what is the value of the flood safety generated by rezoning the targeted land parcels? This value should act as a ceiling to any payment by the government, whether that payment is a direct compensation to landowners, or a subsidy to facilitate development right market transactions. There is discussion of the average expected annual damage due to flooding (50 million EUR/year in Flanders), but how much of this could be averted through land rezoning, is not clear. This information may not exist at all; however, it would be important to research it, as it would make an essential contribution to economically sound government flood policy.

\section{An Alternative Solution: Auction-Based Purchase of Rights}

Lastly, let us mention another alternative to the market of development rights, since its implementation obviously faces serious challenges. The government could consider auctions to purchase development rights from landowners in flood-prone areas. Participation by landowners would be voluntary, and participants would offer their 
development rights at a price that they consider high enough from their own perspective (their "reservation price"). Since different quantities would be offered at different prices, essentially a supply curve of development rights would be created, assuming that enough landowners participate in the auction. Demand by the government, on the other hand, would reflect the value of the public benefits of reduced flood risk, acting as a price ceiling at the auction. If the government makes it clear that these auctions represent the new main policy for rezoning, then landowners will start to offer their development rights since their revenue would be immediate and certain, while full future compensation based on real estate prices is uncertain. This type of certainty would likely help to drive down the purchase price of the rights. Regular auctions, such as annual ones, would be helpful: they would spread the financial burden of the government to several years while at the same time building trust in this new regulatory instrument and allowing landowners to learn about the auction mechanisms by studying already completed auctions. There are various auction types; the actual choice obviously would require a deeper analysis of the Flemish situation.

\section{Some Prerequisites to Successful Environmental Markets}

One of the lessons of this case study is that economic instruments are attractive in theory, but their practical implementation is not always viable, especially in the case of a legally complicated matter such as rezoning of inherited rights. There are also other obstacles, such as the standardisation of the traded product, connecting buyers and sellers, keeping transaction costs low. The number of trading transactions is also of importance: a relatively low number would probably not justify the efforts of establishing a market with all of its institutional requirements. In such a situation, looking for alternative solutions makes sense, including other, less complex economic instruments through which the economic efficiency could still be enhanced.

Another lesson is that developing market-based solutions requires a thorough prior understanding of the envisioned market by investigating questions such as the following: Who are the buyers and sellers? What is their motivation? What alternatives do they have compared to entering the market? Is the product to be traded well defined and understandable for all stakeholders? Would supply and demand likely meet-in other words, is there a scarcity that would drive supply and demand toward each other? Would there be enough participants in the market to make it liquid? How can transparency be ensured? Which institution would be in charge of registering transactions? How would administrative costs be financed?

Finally, even comprehensive research and preparation may not be sufficient to properly design economic instruments from the beginning. The experience with water markets (e.g., in Australia, USA), emission markets (most prominently carbon markets) and effluent discharge trading schemes (especially in the USA) promptly illustrates that a large part of the success of these solutions lies in their ability to evaluate participant feedback, adapt and evolve: learning by doing is often an inevitable component of realising the efficiency gains offered by economic instruments. 
As we can see, the efforts required to create well-operating markets are substantial. The potential benefits, however, are also huge: properly designed and implemented market-based instruments can activate a large number of transactions, delivering valuable economic gains to a wide circle of buyers and sellers.

Acknowledgements Open access of this chapter is funded by COST Action No. CA16209 Natural flood retention on private land, LAND4FLOOD (www.land4flood.eu), supported by COST (European Cooperation in Science and Technology).

Andras Kis is a water economist at REKK, a think tank at the Corvinus University of Budapest, Hungary. He has 20 years of experience working as an environmental economist in Hungary, Central and Eastern European countries and the Middle East North Africa region. For the past 10 years his main focus has been water economics, including water utility regulation, assessment of economic policy instruments, cost-benefit analyses of flood protection measures, and benchmarking of water services.

Gábor Ungvári is senior water economist at the water economics unit of REKK in the Corvinus University of Budapest. Since 1999 he has worked in a series of water-resource focused, interdisciplinary research and economic consultancy programs. His analytical work (among many) targets FRM and the regulatory aspects of WFD measures. He is a member of the Scientific Council of the National Water Directorate of Hungary.

Open Access This chapter is licensed under the terms of the Creative Commons Attribution 4.0 International License (http://creativecommons.org/licenses/by/4.0/), which permits use, sharing, adaptation, distribution and reproduction in any medium or format, as long as you give appropriate credit to the original author(s) and the source, provide a link to the Creative Commons license and indicate if changes were made.

The images or other third party material in this chapter are included in the chapter's Creative Commons license, unless indicated otherwise in a credit line to the material. If material is not included in the chapter's Creative Commons license and your intended use is not permitted by statutory regulation or exceeds the permitted use, you will need to obtain permission directly from the copyright holder. 